\title{
Industrial Development and Combating Unemployment in Arab Countries
}

\author{
Hussein TRABULSI ${ }^{1}$ \\ ${ }^{1}$ Faculty of Economic Sciences and Business Administration, Lebanese University, Lebanon \\ Correspondence: Hussein TRABULSI, Faculty of Economic Sciences and Business Administration, Lebanese \\ University, Lebanon.
}

Received: July 23, 2019

Accepted: August 12, $2019 \quad$ Online Published: August 26, 2019

doi:10.5539/ibr.v12n9p43

URL: https://doi.org/10.5539/ibr.v12n9p43

\begin{abstract}
This research aims to find economic and social solutions through the development of industry in the Arab countries after suffering, for decades, from the lack of interest in order to achieve industrial development and social security, where most of the Arab experiences failed or did not succeed compared to many experiences in the emerging industrial countries.

This research addresses the reasons for this failure to achieve industrial development and its effects on economic and social development and contribute to solve the problem of unemployment in most Arab countries. It also contributes to find solutions for industrial development and social security through some proposals. The results of this study also confirmed the existence of policies focusing on the extractive industries, while the manufacturing industries should be interested in achieving industrial development, reducing the unemployment rate and advancing industrial development.

The statistical approach and the descriptive and analytical approach were adopted to approach and address the problem of unemployment in the Arab world, which is one of the highest in the world. In the research summary, the importance of investment in the field of manufacturing industries, which depends on the human density, so that the greatest possible number of job opportunities can be created, thus contributing to addressing this problem which threatens the security and stability of most Arab countries. Investment in the food industry, furniture industry and other light manufacturing industries can be a solution to the phenomenon of unemployment in the Arab world, in contrast to industries with a capital density associated with extractive industries.
\end{abstract}

Keywords: industry, Arab Countries, GDP growth rate employment, industrial output, industrial investment

\section{Introduction}

The rate of development of the industrial sector and its presence and its contribution to GDP is the main indicator of the classification of the economies of countries between developed and backward. Industrial development is an important pillar of economic development. Industry plays an important role in various economies, including the Arab economies as well as other economies. The industrial sector is the engine of economic development. The industrial sector believes in self-sufficiency and contributes to the development and progress of countries.

Industrialization and industrial development are the pillars of any economically backward country to achieve the desired development. Achieving high economic growth rates can be achieved through industry development. This development can also be achieved through the development of industry. This development can contribute to the highest possible operating rates. Many sectors of industries that do not rely on capital density are creative in their ability to absorb high unemployment rates in third world countries and can create employment opportunities for young people entering the labor market after graduation.

The development of industrial strategies that can direct investments to sectors of human density away from the capital intensity can contribute to solving the problem of unemployment, especially as it is one of the most important problems experienced by most of the Third World countries. We also note that the application of good governance is a key pillar in achieving industrial development and social security.

The main objective of this research is to find some solutions by proposing proposals that contribute to the 
treatment

The following forms:

- What industrial policy of the Arab countries can support the process of industrialization and lead to industrial development? Any design of industrial policies can provide job opportunities for millions of unemployed in the Arab countries? What industrial policy can contribute to industrial development and social security?

There are certainly many questions that can be asked about the industrial sector and the role it plays in economic development in Arab countries. This study analyzed the factors that affect the growth and development of the industrial sector, and then tried to formulate political solutions and development strategies that would achieve development and achieve self-sufficiency, despite the difficulty of statistics.

In this research we relied on the statistical and analytical approach to contribute to tackling the problem of unemployment and industrial development. In many cases, we tried to develop data and review many sources in order to adopt consistent and reliable statistics and analysis based on them, in order to promote the process of industrial and economic development, especially since no economic development without industrial development.

\section{The Importance of Industry in Modern Economy}

Industrial development in all cases, regardless of the method followed, is a cornerstone of comprehensive economic and social development, and it is difficult to achieve a balanced development that leads to progress and development in society without concern for industrial growth in a scientific, systematic and balanced manner based on objectives and strategies The process of economic development in general, in order to achieve industrial development in particular.

Industry is the primary measure of development and progress of countries, and industry is the mainstay of economic and social development. It also plays a distinct role in achieving economic, social and development goals. The importance of manufacturing in the national economy of any country stems from the many positive dimensions of this process. The most prominent of these dimensions are:

1. The high added value resulting from the manufacturing process, which accounts for more than $90 \%$ of the wealth of some developed countries economically. Value added in manufacturing industries also increases in industries requiring intensive technology and technology used in this industry. This added value exists in the extractive industries but it does not take an upward path; however, a path of change in some years negatively or positively, so that the prices of raw materials extracted in a year may increase due to certain conditions and factors and then decrease strongly. This affects the revenues of countries exporting raw materials in the world, which are in general third world countries.

2. Industry is a creative sector on more than one level. The industry produces goods of various kinds, which may contribute to the decline in the rate of these commodities import or may become a source of foreign currency when they are exported abroad. The industry is creating employment opportunities for a large segment of population at all scientific and technical levels, which will contribute to the continuity of stability and the achievement of social security. This is the most important pillar of this research: the creation of jobs and the achievement of industrial, economic and social development.

3. The industry is the only and almost obligatory corridor for any country in the world that wants to emerge from the clutches of the economically developed countries, thus achieving the real independence of these countries and improving their economic position despite the challenges of the elements of industrial development. Most of the third world countries have become exporters of natural or agricultural raw materials in the process of international division of labor. The share of raw materials in international trade has declined significantly since the Second World War. It was 55\%, compared to $45 \%$ for manufactured goods. This equation changed in the 1970 s and 1980s, to become $65 \%$ for manufactured goods and $35 \%$ for materials in international trade. Consequently, investment should be made in industry to use raw materials, free industry from association with industrial countries, reduce unemployment and support economic structure.

\section{Development of the Industrial Output of the Arab Countries 1990 - 2016}

The gross industrial output of the Arab countries grew over a quarter century, so that it doubled more than five times from 151 billion dollars in 1990 to 815.9 billion dollars in 2015 as shown in Table 1 . The growth rates of this industry varied from one Arab country to another. The growth rate is relatively high as the volume of Egyptian industrial output went from $\$ 7.4$ billion in 1990 to $\$ 98.6$ billion or about 13 times in 2015. Saudi Arabia has moved the value of industrial output from \$ 46 billion in 1990 to more than $\$ 243.6$ billion in 2015 as 
well as the United Arab Emirates built up from \$ 18.4 billion in 1990 to more than $\$ 128.9$ billion in 2015, and Lebanon has moved the value from $\$ 252$ million to more than $\$ 3.7$ billion over the same period.

What has been achieved at the level of some Arab countries, throughout the period between 1990 and 2016, cannot be underestimated, although we believe that it was better than it was at the level of the Arab world first and at the level of more than a second country. This would be the case if some policies aimed at supporting the industrial sector were adopted, and by coordinating some Arab manufacturing policies at the level of all the Arab countries in general.

Most of the development of the Arab industrial output was the result of the development of the extractive industries in most Arab countries, at the expense of the manufacturing industries, which did not give enough attention and support to the advancement and growth similar to extractive industries. The adoption of certain policies aimed at supporting the industrial sector and the coordination of Arab manufacturing policies at the level of all Arab countries can contribute to a strong start for this industry due to two main reasons, first of which is the size of the large Arab market and secondly the increase in the purchasing power of the Arab consumer.

Table 1. The development of industrial output in some Arab countries

\begin{tabular}{lllllllll}
\hline & \multicolumn{2}{c}{$\mathbf{1 9 9 0}$} & \multicolumn{2}{c}{$\mathbf{2 0 0 0}$} & \multicolumn{2}{c}{$\mathbf{2 0 1 0}$} & \multicolumn{2}{c}{$\mathbf{2 0 1 5}$} \\
\hline & GDP\% & \multicolumn{1}{c}{ Million\$ } & GDP\% & Million\$ & GDP\% & Million\$ & GDP\% & Million\$ \\
\hline Arabic countries & $\mathbf{3 8 . 2}$ & $\mathbf{1 5 0 9 6 9 . 1}$ & $\mathbf{3 9 . 2}$ & $\mathbf{2 9 2 0 4 7}$ & $\mathbf{4 3 . 5}$ & $\mathbf{9 0 7 3 1 3}$ & $\mathbf{3 3 . 6}$ & $\mathbf{8 1 5 8 9 8}$ \\
Jordan & 19.1 & 744.6 & 16.4 & 1381 & 20.1 & 5314 & 19.2 & 7211 \\
Emirates & 54.8 & 18426 & 41.8 & 43597 & 40.6 & 116703 & 34.4 & 128965 \\
Tunis & 23.6 & 2977 & 19.5 & 4180 & 21.8 & 9643 & 20.5 & 8810 \\
Algeria & 34.6 & 21449 & 45.1 & 24703 & 39.0 & 64144 & 24.3 & 44171 \\
Saudi Arabia & 43.9 & 46017 & 46.8 & 88184 & 52.6 & 277173 & 37.3 & 243696 \\
Sudan & 8.2 & 2012 & 13.9 & 1860 & 17.4 & 12112 & 14.5 & 13046 \\
Syria & 23.4 & 3256 & 31.7 & 5985 & 29.5 & 17679 & 7 & NA \\
Iraq & 61.3 & 8641 & 65.2 & 21920 & 54.1 & 66024 & 42.1 & 60401 \\
Oman & 50.9 & 5951 & 56.0 & 10924 & 57.1 & 33547 & 45.3 & 31849 \\
Qatar & 50.6 & 3747 & 65.7 & 11698 & 61.6 & 77082 & 45.9 & 76933 \\
Kuwait & 51 & 9336 & 54.9 & 20709 & 59.4 & 71188 & 50.1 & 57137 \\
Lebanon & 9 & 252 & 11.4 & 1970 & 7.8 & 2886 & 8.1 & 3766 \\
Libya & 35.5 & 11654 & 46.1 & 15926 & 71.3 & 52613 & 38.9 & 8036 \\
Egypt & 20.8 & 7381 & 24.8 & 24747 & 29.8 & 65165 & 29.7 & 98645 \\
Morocco & 21 & 5418 & 18.4 & 6816 & 18.0 & 16468 & 18.2 & 18009 \\
Yemen & 23.5 & 2118 & 36.7 & 4006 & 31.8 & 9922 & 13.2 & 3173 \\
\hline
\end{tabular}

The source is the researcher's preparation based on different numbers of the unified Arab economic decision.

Numbers issued during the years 1990 to 2017

NA: Not available (due to prevailing security situation in Syria)

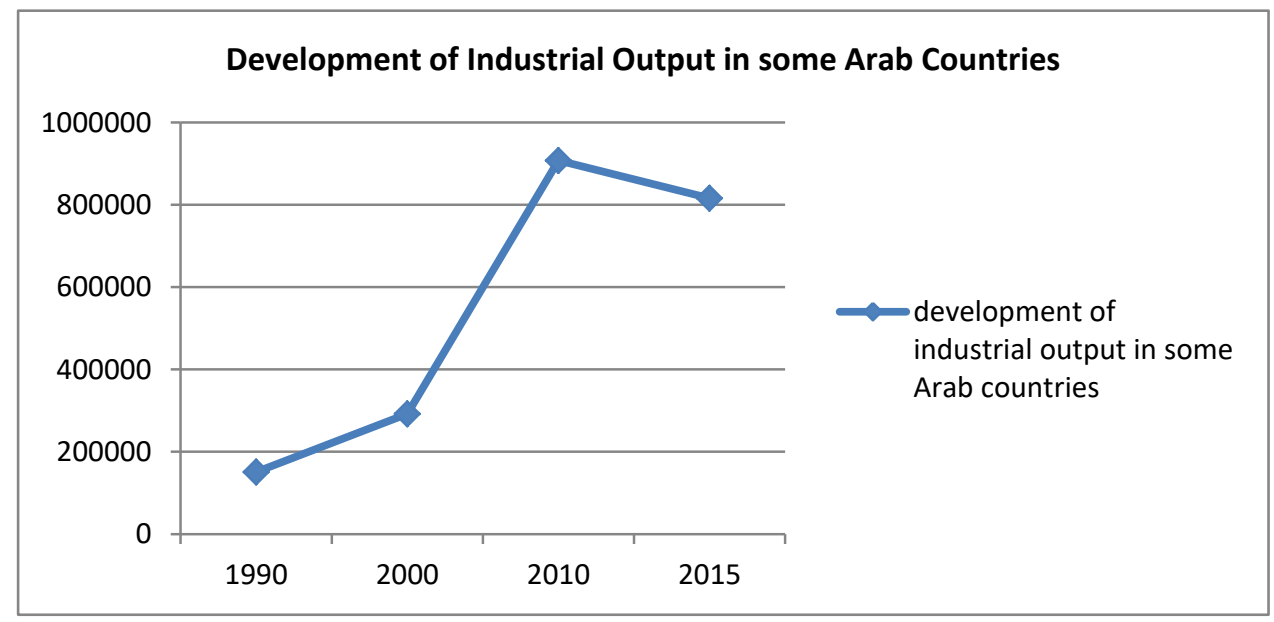

Figure 1. Development of industrial output in some Arab countries (Based on table 1) 
During this period, the share of industrial output of the Arab countries in GDP declined from $38.2 \%$ in 1990 to $33.6 \%$ in 2015 based on table -1-. Most of the Gulf Cooperation Council (GCC) countries maintained contribution to GDP relatively high, with an average of over $40 \%$ for all these countries, and the highest percentage in the Emirate of Kuwait, where it exceeded 50\% in 2015. The study of the United Nations Conference on Trade and Development on the extractive industry and the importance and impact in the Arab countries that the first five countries in the world depending on the export of oil and gas are from the Arab world, five other Arab countries were among the top 20 countries in varying ranks depending on the oil and gas extractive industries ${ }^{1}$. In contrast, in the non-oil Arab countries, the contribution of industry to GDP was less than $20 \%$ in 2015; this contribution was the lowest in Lebanon, reaching 8.1\% of GDP in 2015 compared to 9\% in $1990^{2}$. It should be noted that the contribution of industry in Iraq, Oman and Qatar exceeded $40 \%$ of GDP. Actually, this is the role of extractive industries in many Arab countries, mainly oil and gas extraction, which dominates most of the Arab industrial output. These industries depend on capital density. They do not create many jobs, while manufacturing industries in Arab countries generally do not increase their contribution to GDP. The total is about $15 \%$, it is worth mentioning that these industries are the ones that must deal with unemployment in the Arab countries, which is among the highest rates in the world and which is the most important problem experienced by the Arab countries, which always contributes to the social tensions and the instability experienced by many Arab countries, especially in the current stage since 2011 till 2019, where the social and economic conditions are the starting point and the engine of the chaos and destruction experienced by many Arab countries.

Table 2. Contribution of manufacturing industry to the total output of some Arab countries \%

\begin{tabular}{|c|c|c|c|c|c|c|}
\hline & 1990 & 1995 & 2000 & 2005 & 2010 & 2015 \\
\hline Arabic countries & 11,8 & 11,9 & 10,7 & 9,6 & 9,6 & 8,8 \\
\hline Jordan & 13,4 & 12,9 & 13,5 & 16 & 16,8 & 16,5 \\
\hline Emirates & 7,8 & 9,7 & 13,1 & 10,6 & 9 & 9.2 \\
\hline Tunis & 16,8 & 19,0 & 14,8 & 15,7 & 15,5 & 16.2 \\
\hline Algeria & 12 & 8,5 & 5,8 & 4,5 & 4,1 & 4.5 \\
\hline Saudi Arabia & 8,1 & 9,6 & 9,7 & 9,5 & 11 & 11.7 \\
\hline Sudan & 8,1 & 6,8 & 6,8 & 8,5 & 8,1 & 8,9 \\
\hline Syria & 8,5 & 8,8 & 4,2 & 7,5 & 4,7 & 4 \\
\hline Iraq & 4,7 & 7,8 & 0,7 & 1,8 & 2,6 & 3.5 \\
\hline Oman & 3 & 4,6 & 5,7 & 8,5 & 10,8 & 10,2 \\
\hline Qatar & 12,8 & 8,4 & 5,4 & 9,9 & 9 & 9,8 \\
\hline Kuwait & 11,6 & 10,9 & 6,9 & 7,2 & 5,6 & 6.2 \\
\hline Lebanon & 9 & 9,1 & 11,4 & 6,3 & 7,8 & 6,9 \\
\hline Libya & 7,7 & 7,0 & 6,7 & 5,0 & 6,2 & 3,6 \\
\hline Egypt & 16,9 & 16,8 & 18,4 & 16,7 & 16,1 & 16.7 \\
\hline Morocco & 18,4 & 18,4 & 16,3 & 14,9 & 14,1 & 13.3 \\
\hline Yemen & 9,4 & 11,6 & 5,1 & 8,9 & 8,4 & 8.5 \\
\hline
\end{tabular}

The source is the researcher's preparation based on different numbers of the unified Arab economic decision.

United Arab Economic Reports 1995-2014

\footnotetext{
${ }^{1}$ Extracting Industries: Optimizing Value Retention in Host Countries UNCTAD (2012

${ }^{2}$ Various numbers of the unified Arab economic report
} 


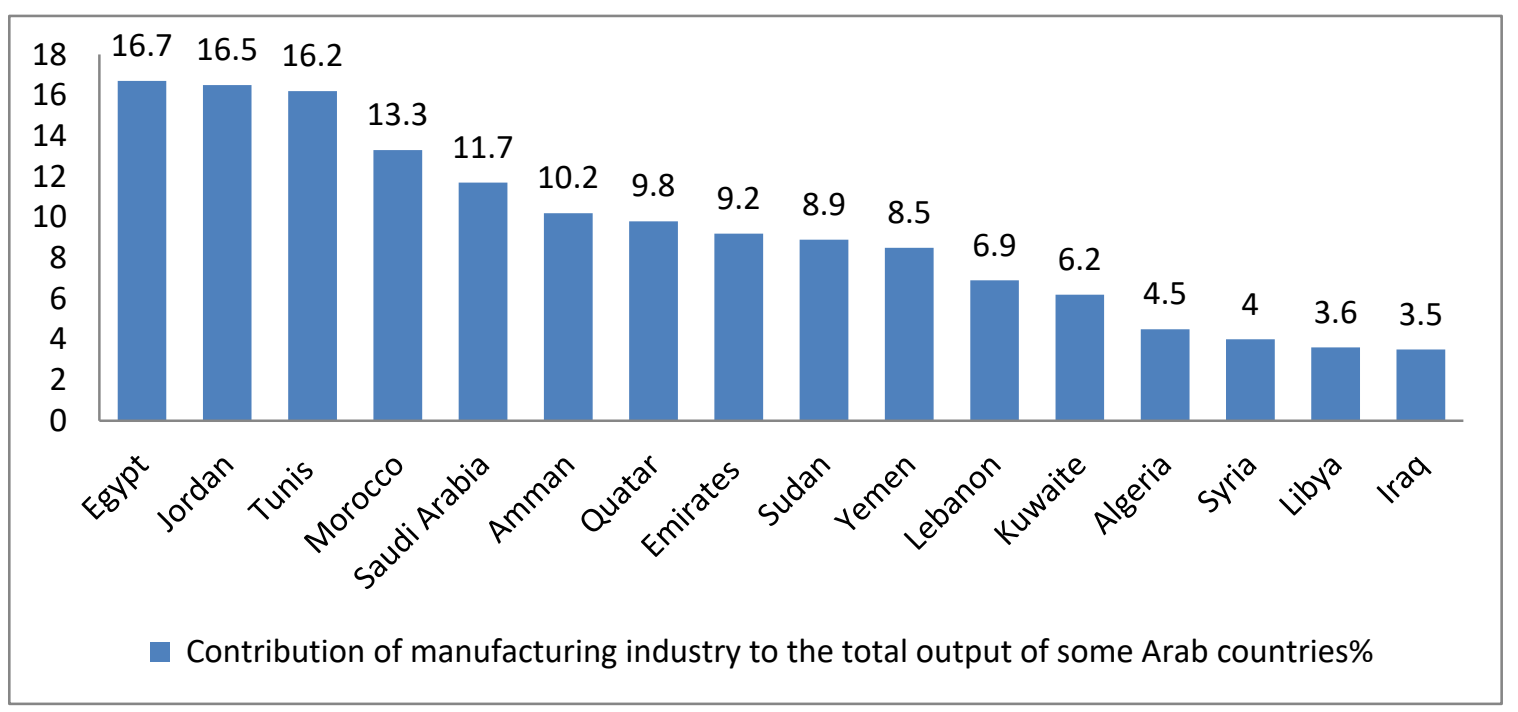

Figure 2. Contribution of manufacturing industry to the total output of some Arab countries

Despite the decline in oil prices and the decline in the value of extractive industries in 2015, the contribution of manufacturing industries did not exceed 11\% of the GDP of the Arab countries, as shown in Figure 2, though the share of world manufacturing exports amounted to $64.6 \%^{3}$ of the world's total, compared to $35.4 \%$ for the primary agricultural exports. The proportion of manufacturing exports in Asia reached $77 \%$ and in Europe to 75\%, while not exceeding 20.9\% in the Middle East Arab region as a result of the dependence of the Arab region on exports of extractive industries. Egypt is at the forefront of the Arab countries in the contribution of manufacturing industries in the gross domestic product where the contribution of these industries is $16.7 \%$ of GDP, followed by Jordan and Tunisia with a contribution of $16.5 \%$ and $16.2 \%$, While the share of manufacturing exports in Saudi Arabia reached only 11.7\% in 2015, a weak contribution, and Oman achieved $10.2 \%$ in 2015, according to Table -2-. This shows the weakness of the Arab manufacturing industries and their inability to develop and grow so that they can leverage Arab economies and bear the solutions required for the problems of economic development, instability and social security in the Arab countries, which could ease the economic dependency of these countries abroad.

\section{Industry and Employment}

Employment levels in the Arab industrial sector have declined gradually over the last three decades in terms of the size of the Arab labor force, although there has been a limited increase in the number of workers in this sector during this period. The percentage of workers in Arab industry in 1985 was about $26 \%$ of the total labor force in the Arab world, falling to $20.4 \%$ in 1995 , to $16.9 \%$ in 2010, and between $16.5 \%$ and $16.8 \%$ in 2017 . The share of workers in the agricultural field in the developed countries in general is between $2 \%$ and $6 \%$ of the total labor force and is increasing in some Asian countries such as Korea, Taiwan and others. We note that any job opportunity in the field of productive sectors, agriculture or industry (especially manufacturing) contributes to the creation of two jobs in the field of various services (banking, insurance, transport ...). Therefore, the importance of employment in the industrial sector is not limited to the numbers and percentages of employment in this sector, but rather their effects on creating job opportunities in the various services sectors in the economy, knowing that every job in the industrial sector can contribute to creating jobs in the service sector and perhaps more in some situations. Therefore, the importance of developing the industrial sector in this direction can be the only hope in the Arab countries to contribute to solving or alleviating the unemployment problem now and in the future, in light of the decline of the ability of the agricultural sector to absorb future labor numbers, which will exacerbate the unemployment crisis and the resulting stability and its implications for the economy and politics.

The Investment in manufacturing industries such as the furniture industry in Egypt, where the industry is famous, contributes to creating more jobs directly. This, in turn, can contribute to the double creation of jobs indirectly, which would achieve industrial development and reduce unemployment.

\footnotetext{
${ }^{3}$ United Arab Economic Report 2013, p. 85
} 
We note from Table 3 that since 2005 there is an inverse relationship between the percentage of workers in the industrial sector and the unemployment rate. The unemployment rate rose steadily during this period from 2000 until 2015, while the proportion of workers in the industrial sector has been steadily declining.

Table 3. Employment in Arab industry and registered unemployment rates

\begin{tabular}{|c|c|c|c|c|c|}
\hline & 2000 & 2005 & 2010 & 2012 & 2015 \\
\hline Number of employees in industry (million) & 18.9 & 18.8 & 20.2 & 20.4 & 22 \\
\hline Percentage of employees in industry to total labor force $\%$ & 18.8 & 17 & 16.9 & 16.8 & 17.8 \\
\hline Unemployment rate & 20.0 & 14.0 & 14.6 & 17.2 & 16.8 \\
\hline
\end{tabular}

Source: Various numbers of the unified Arab economic report

Srour H. Economies of Economic Countries in the Arab Countries and Prospects of Arab and Regional Cooperation, 2006.

Table 4. Total Arab Labor Force and employees in industry (million)

\begin{tabular}{|c|c|c|c|c|c|c|}
\hline & 1995 & 2000 & 2005 & 2010 & 2012 & 2015 \\
\hline Number of employees in industry (million) & 17.2 & 18.9 & 18.8 & 20.2 & 20.4 & 22 \\
\hline Total Arab Labor Force (million) & 71.4 & 92 & 105.8 & 122 & 121.4 & 124 \\
\hline
\end{tabular}

The source is the researcher's preparation based on different numbers of the unified Arab economic decision.

United Arab Economic Reports 1995-2014

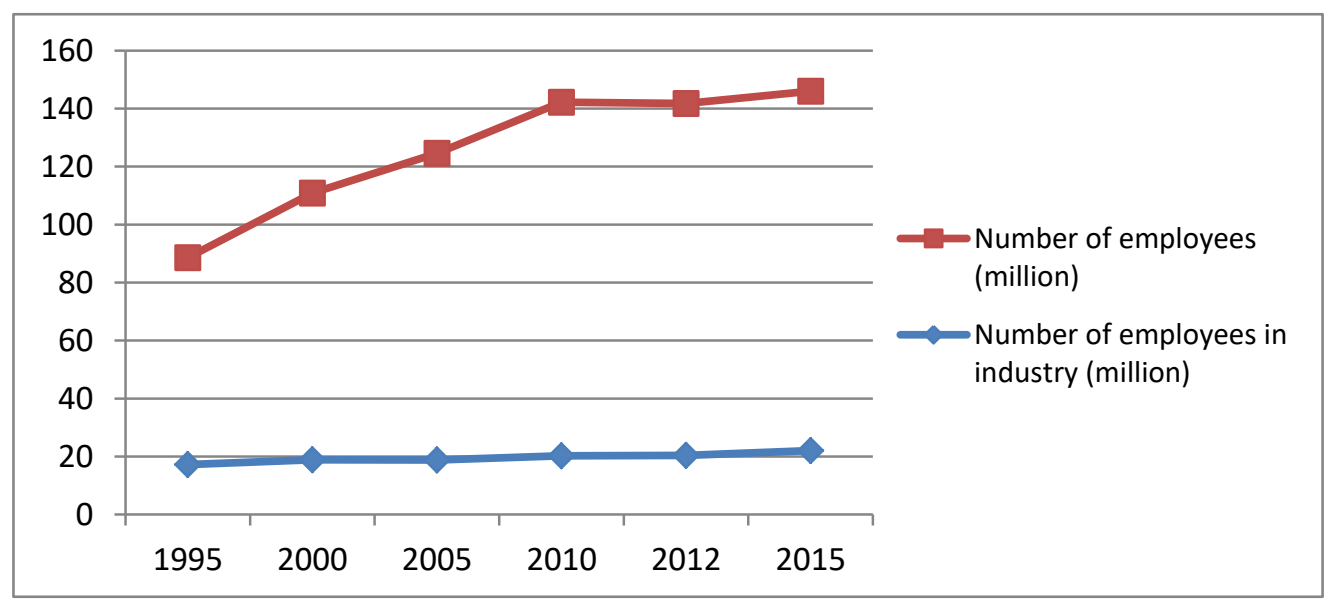

Figure 3. Total Arab Labor Force and employees in industry (million)

However, there has been a slight improvement in the proportion of workers in the industrial sector in 2015, but the unemployment rate remains very high, which is three times the average of the world unemployment rate, which is estimated at about $5.8 \%$ by 2015 . We also note that the total labor force has risen significantly more than the proportion of workers in the industrial sector, according to table No. 4, this is the result of poor interest in manufacturing industries that contribute to the creation and increase of employment.

The percentage of workers in the industrial sector varies from Arab to other countries, depending on the size of the manufacturing industries and the nature of these industries, which depend on the capital intensity in the extractive industries and the oil and gas industry, which is the case of most of the Gulf countries or industries that depend on human density in Egypt, Tunisia and Morocco. Light food industries, textiles, garments and furnishings which require intensive labor, can contribute to the creation of many jobs and form the basis through which to address the crisis of high unemployment in these countries.

Returning to the high unemployment rates in the Arab world, it should be noted that all Arab countries suffer from the unemployment crisis and even the oil-rich Gulf States are witnessing a remarkable rise in unemployment rates among Gulf citizens. Some estimates indicate that unemployment rates among Saudi citizens are higher than $20 \%$ in 2019. The Kingdom has so far resorted to the Saudis for jobs in the public sector between 2010 and 2020. But we point out that the main problem is the lack of focus and support for 
manufacturing industries that contribute to the creation of direct jobs and reduce unemployment.

Companies and institutions were told that Saudi citizens should replace expatriates in the catering and other sectors in order to reduce the phenomenon of unemployment and the resulting social instability, economic consequences, and so forth. Based on these facts and the aggravation of the unemployment crisis at the level of all Arab countries, we believe that the industrial sector and investment in it, especially the manufacturing industries, represent the only hope for these countries to address the problem of unemployment or alleviation of current and future, especially as the proportion of workers in the agricultural sector is declining significantly. Growth rates remain high over the next two decades due to high rates in population significantly over the past three decades, which threatens to exacerbate the unemployment crisis and threaten the economic and social stability of the Arab countries worse than we are currently experiencing along the Arab geography.

\section{Conclusion and Recommendations}

Over the past five or six decades, Arab countries have relied on many industrial development policies for their economic and social development problems, based on the principles and ideas of most well-known schools of thought, from excessive socialism to liberal socialism to liberalism and Keynesianism. In the final analysis we can say that some successes have been achieved in some countries, but they have not lived up to the expected ambitions. In comparison with the successes in many Asian countries and others, we believe that the Arab policies in this context during these decades in general proved their sterility and failure to solve and address The economic and social problems of the Arab countries, especially unemployment and redistribution of income in a way that achieves greater social justice. In the same period, many countries started worse than some Arab countries in the 1950s and 1960s and were able to make big strides in development and redistribution of income (Korea, Taiwan, etc.).

In order to address the problem of unemployment in the Arab countries, it is necessary to reconsider the Arab industrial structure and how to develop it so as to be able to contribute to addressing the unemployment problem of a structural nature in most Arab countries.

In the following we present our recommendations:

1. Providing and developing the legal and legislative environment and infrastructure suitable for the development of existing industries and the establishment of new modern industries, where the laws and legislation that sponsor investment in industry and others are not qualified and sufficient to encourage the business environment and investment.

2. The success of the model, which is based on the interaction of the public and private sectors, requires States to be present and oriented towards the economy and to encourage the private sector to initiate through the many subsidies, incentives and facilities that the State can provide to the sector, such as credit, protection...

3. Political and administrative corruption is one of the most prominent features of the systems in the Arab countries, so any industrial development process or other requires confronting the fight against corruption in all possible ways, otherwise the continuation of corruption will distort the desired development process. Corruption results in the dominance of small number of people on both wealth and power while keeping large segments of society submerged and marginalized. Hence, the process of political reform and addressing corruption must be given sufficient importance to achieve the objective of any economic and social development policy.

4. Adopting Arab industrial policies at a level that each country should take into account modern technological developments and works to improve the quality of Arab industrial goods and products in order to enjoy the competitive advantages required for foreign goods in both domestic and foreign markets.

5. Adopting effective policies and strategies in Arab cooperation in general and industrial cooperation among Arab countries, especially in helping to provide opportunities for industrial investment and upgrading the efficiency of existing productive units and to benefit from economies at the level of the Arab market as a whole.

6. Increase Arab spending on scientific research and development, and work to link existing scientific research centers in Arab countries to facilitate coordination among them. In this context, we note that the Arab countries are among the lowest groups in the world spending on scientific research, since the average per capita Arab research and development is $\$ 8$ per year; this is certainly a meager amount and cannot achieve sustainable development in scientific research, while the average of spending on military for the individual in the Gulf countries is up to $\$ 1500$ per year.

Thus, the equation is for almost every $\$ 1$ spent on $R \& D, \$ 200$ is spent on other military expenditures. However, the percentage of Arab spending on scientific research and development does not exceed $0.2 \%$ of the Arab GDP, 
which means about 4.5 to 5 billion dollars annually, while this ratio is very small given the population in the Arab countries and the proportion of expenditure on research and scientific of GDP in developed countries.

7. Finally, to reduce the phenomenon of unemployment rampant in the Arab countries and to achieve greater social stability, it is necessary to initiate a large investment project in manufacturing industries based on modern technologies, which can lead to reducing the cost of production and improve the quality of goods. In this context, emphasis must be placed on directing investments to the manufacturing sector, which requires labor intensity, especially as it has the potential for success such as the textile and clothing industries, and the light and medium food industry. This would absorb the largest number of job seekers and alleviate the unemployment crisis in various Arabic countries. The focus on small and medium-sized enterprises can be a great lever to solve the problem of unemployment as this type of project is a major source of job creation net, as it is estimated in the United States that in the seventies of the last century the period of unemployment that these projects were generating eight out of ten jobs in the United States at that stage.

Supporting and developing these kinds of projects and institutions can contribute to solving the problem of unemployment and contribute to alleviating the great pressure on the Arab labor markets and supporting social stability in the Arab countries, which is an essential pillar for these countries to move forward in the desired development process.

In addition to the above, it is necessary to survey the Arab wealth so that it can be exploited and work to strengthen Arab cooperation in all economic, investment, exchange and other fields. It is also necessary to encourage and develop the capital markets in the Arab countries to be able to secure the needed financing requirements for a major industrial investment renaissance.

\section{References}

Al - Kafri, A., \& Abdullah, M. (2008). The Economies of the Arab States and Joint Arab Action, Hashim Press, Damascus. 2008.

Assidon, E. (2002). les théories économiques du développement 3ème èd. Paris La Découverte 2002.

Dagher, A. (1995). l'Etat et l'économie au Liban, Action gouvernementale et finances publiques de l'indépendance à 1975. Beyrouth; Centre d'études et de recherches sur le Moyen- Orient Contemporain (CERMOC), 1995.

Dagher, A. (2013). For Arab development policy, different starting points for neo-liberalism, Knowledge Forum, Beirut, 2013.

Guellec, D., \& Pierre, R. (2001). les nouvelles théories de la croissance. Paris: La Découverte, 2001. https://doi.org/10.1787/eco_studies-v2001-art12-fr

Impact of Industrial Policies on the Competitiveness of SMEs, United Nations Economic and Social Commission for Western Asia (ESCWA) New York.

Issa, N. (1996). Manpower and Employment Policy in Lebanon, Beirut, Lebanese Center for Studies, 1996.

La Faye, de M., Elsa, E. M., \& Pepito, O. A. (eds). (2007). Institutions et développement: La Fabrique Institutionnelle des Trajectoires de Développement, Rennes: presses universitaires de Rennes France, 2007 (Economie et Société).

Lebanese Center for Studies, Any industrial policy for Lebanon? A Different Approach to the Role of the State in the Economy. 2005

Makdisi, S. (2012). The Arab Economic Cluster and Globalization on the 21st Century. American University of Beirut.

Murad M., \& Trabulsi, H., (2019). Economic Growth Analysis of a Singapore: Simultaneous Equations Model. Journal of Business \& Financial Affairs, 2019

Nyahoho. E et pierre- paul p. Le commerce international, théories, politiques et perspectives Industrielles, préface de Christian Deblock. Québec: presses de l'université du Québec 1997.

Rizk, A. (2009). Emerging Economies in the World, Developments Scenic Models, Dar Al-Farabi, Beirut, 2009.

Sadek, A. T. (2002). Division of privatization policies in the Arab countries. Arab Monetary Fund, Institute for Economic Policy. Abu Dhabi for printing and Publishing, 2002.

Sid, A. K. A. (1996). Economie politiques de la transition dans les pays en développement : Le cas de la Syrie. Paris: Edition publisud, 1996. (Collection le développement dans les faits). 
Srour, H. (2006). The Economies of Arab Countries and Horizons of Arab Regional Cooperation, Freedom press, Beirut, 2006.

Reports:

Annual Report, 2007, Arab Monetary Fund, Abu Dhabi, United Arab Emirates. 2008.

Arab Agricultural Statistics Yearbook, Arab Organization for Agricultural Development, Volume 33/2013, Khartoum 2013.

Arab Fund for Economic and Social Development

Consolidated Arab Economic Report, 1990 to 2016 issued by the General Secretariat of the League of Arab States.

Organization of Arab Petroleum Exporting Countries - Abu Dhabi.

\section{Copyrights}

Copyright for this article is retained by the author(s), with first publication rights granted to the journal.

This is an open-access article distributed under the terms and conditions of the Creative Commons Attribution license (http://creativecommons.org/licenses/by/4.0/). 